\title{
A 110 ÉVE SZÜLETETT MÉREI FERENCRE, A KLINIKAI PSZICHOLÓGUS SZAKMA ALAPÍTÓ TANÍTÓMESTERÉRE EMLÉKEZÜNK
}

\section{AJKAY KLÁRA² - BAGDY EMỐKE ${ }^{1,2}$ - DOBOS EMỐKE ${ }^{2}$ - ERDÉLYI ILDIKÓ ${ }^{2}$ - FALUS FERENC ${ }^{2}$ - KAPUSI GYULA² - PAJOR ANDRÁS ${ }^{2}$}

\author{
${ }^{1}$ Károli Gáspár Református Egyetem Pszichológiai Intézete \\ ${ }^{2}$ Pszichodráma Múhelycsoport \\ E-mail: info@bagdyemoke.hu
}

Beérkezett: 2019. december 31. - Elfogadva: 2020. február 29.

\begin{abstract}
Írásunk a Pszichodráma Mühelycsoport (röviden MCS) együtt gondolkodó emlékezésének terméke. Arra törekedtünk, hogy mindmáig aktív csoportéletünk keletkezését is abba a történeti folyamatba ágyazzuk, amelyben a „Lipótmezön” megtörtént a klinikai pszichológia „honfoglalása”. Mérei Ferenc, „a Tanár úr” teremtô és alapitó személyisége a hazai klinikai lélektan gyakorlatának. Emlékezésünkben Mérei Ferenc személyiségét, tanári mivoltát, pszichológusi hivatásszemélyiséget formáló munkáját szeretnénk láttatni, érzékeltetni. Rorschachozásra tanitása is szerves részét képezte annak a szakmára nevelö munkának, amelyben egységes volt az elméleti tudás követelménye, a gyakorlat (a „csinálás”, ahogyan Ő nevezte) és a pszichológusi magatartás csiszolgatása. Ez az írás Mérei alkotó tehetsége iránti tiszteletünk kifejezése és szakmateremtô tevékenységének mementója. Az irásban az emlékezố gondolkodás egyes tématerületei szerinti kérdéseinket követjük, ekképpen nyolc kérdésre válaszolunk.
\end{abstract}

Kulcsszavak: Mérei, pszichodráma, Rorschach 
Hogyan született és bontakozott ki a „Mérei-iskola” (1965-1974)?

A Tanár úr 1964-ben került a „Lipótra”, ahol bámulatos gyorsasággal szervezte meg az elsô „Pszichodiagnosztikai Laboratóriumot”. (1970-tôl ez Klinikai Pszichológiai Laboratórium néven múködött.) 1965-tôl már egyetemi klinikai gyakorlóhely megbízatást kapott az ELTE-tôl. Az elsô, 1963-tól egyszakos alkalmazott pszichológusok szakmai gyakorlatra kerülhettek az OIE-be (Országos Ideg- és Elmegyógyászati Intézetbe), így a Mérei Laboratóriumba is. Informális csatornán terjedô hír volt Méreirôl, hogy börtönviselt, '56-os „vétkes”, aki amnesztiát kapott, de állást csak egy olyan „veszélytelen” és szabálytalan intézetben szerezhetett, mint a „bolondokháza”, a Lipótmezô, ahol ôt Kun Miklós fôorvos ajánlására Mária Béla költô-igazgató jóindulattal fogadta (bôvebben Szakács, 2010).

A Lipót sokakat tudott védelmezni ezekben az idôkben, noha ekkor már a Kádár-féle három T (tiltás, tûrés, támogatás) világában éltünk, túl az ominózus VII. Pártkongresszuson is, ahol a sokat idézett szlogen elhangzott: „Aki nincs ellenünk, az velünk van.” A politikai enyhülés, konszolidáció és társadalmi „béke” éveiben jártunk, Méreinek pedig menedéke és „tündérkertje” lett a Lipótmező. Szervezô tehetség is volt, hiszen amikor az elsô egyszakos pszichológuscsapatunk az ELTE-rôl gyakorlatra érkezett a Lipótra, olyan szervezettségi szintú pszichológiaszakmai és társas életbe csöppentünk bele, amilyenrôl az egyetemi zord idôk alatt eddigelé nem is álmodhattunk. Az akadémikus pszichológia elefántcsonttornyából kiszabadulva éppen az elmegyógyintézetben találtuk meg a valódi szakmai életpezsgést, tanulást. Szigorúan felépített és számonkért gyakorlatok, teszttanulás, Rorschach-órák, a Tanár úr szerdai szemináriumai - melyek a híres pavlovi szerdákat asszociálták -, betegekkel folytatott explorációk, beszámolók, írásos munkák, sok feladat terhelôdött ránk, mégis rengeteget és lelkesen dolgoztunk, mert azt kaptuk, amire kezdettôl vágytunk: ez a pszichológia az emberrốl szólt, és az embert tanultuk kórlélektanában is - önmagunk megértése, érzelmi reflexióink értelmezése útján. Ma ezt önreflektív munkának szokás nevezni, a lényeg ugyanaz. Mérei avantgarde szellemisége magával ragadott. Mindig tanított, bármit mondott. Kötelezô volt saját viszonyulásmódunk megértése is, dinamikai gondolkodást tanultunk tôle.

Heten kerültünk a Lipótra gyakorlatra, és itt kétségtelenül Mérei volt a fônök még Kun Miklós fôorvos is hagyta magát vezényelni, mert Mérei rendkívüli ambícióval építette fel képzésünk rendszerét. Az akkori, elsố alkalmazott ági klinikus csapat tagjaiként (Pál Mária, Kardos Mária, Münnich Iván - ốk már nincsenek köztünk -, Juhász Erzsébet, Kiss Eszter, Mórotz Kenéz, Bagdy Emôke) az akkori Országos Idegés Elmegyógyintézet pszichológusaihoz kaptunk beosztást gyakorlatra, és így rendre jártunk Szegedi Márton diagnosztikaóráira, Szakács Ferenc betegvizsgálataira és esetmegbeszélöire, de a gyermekosztályon dolgozó S.T.ZS. (így rövidítettük Somogyi Tóth Zsuzsa nevét) is sokféle tesztet tanított (gyermekteszteket, színteszteket).

Gyurkovics Tibor (a költô) a rehabilitációba, Hajtmann Pál a munkaterápiába, Hegedûs Imre a szkizofrének világába és a piktogramba vezetett be bennünket. Állíthatjuk, hogy minden lehetséges időnkben a Lipóton lebzseltünk, sok „szabad interakcióban” volt részünk, élveztük a pallérozódásunkat. 
Ma is ráámulhatunk a lelkesedésünkre, ahogyan Mérei Tanár úr beszervezhetett minket Szegedi Márton Wechsler-teszt-standardizáló munkájába, és mi hatan (Münnich Iván kivételével, aki Szakács Ferenccel szövetkezve sportrajongóként a sportpszichológia felé indult el) el is végeztük azt. Késôbb Szegedi Márton a deviancia-, kriminalitáskutatás hazai jelese lett. Odaadóan jártuk az országot a Wechsler-dobozzal, hogy pl. 35 éves vidéki kazánkovácsot vagy dunántúli segédmunkásokat találjunk, mert ezt kívánta a standard reprezentatív minta. Talán már az eddigiekból is kitûnik, hogy a Tanár úr a Lipót világát az általa központinak tartott „együttes élmények” és csoportkultúra otthonos fészkévé tette, jó volt oda tartozni a vonzáskörébe. Atmoszférateremtó ereje bámulatos volt. A „múhelység” volt az eszménye, ez a „teljesítményközpontú, az együttesség melegét és életszagú konfliktusait hordozó mikrovilág" (Bagdy, 1985), amelynek kultúrájára megtanított minket. 1968-ban szereztünk diplomát, és közülünk hárman a Lipóton maradtunk osztályos pszichológusként.

\section{Mit tudtunk a Tanár úrról a klinikai gyakorlat idején?}

A politikai hátterérôl többet tudtunk, mint a munkásságáról. Legalábbis vajmi keveset hallottunk korábban a jeles múveirôl. Szociálpszichológia-órán ámultunk rá elôször, hogy Mérei nem csupán klinikus. Pataki Ferenc - aki briliáns elôadó volt - Méreirôl ôszinte elismeréssel tudott beszélni. A Gombozó Gyermek, Az országépitô gyermek, Az együttes élmény, A pár és a csoport, Az utalás (melyet Mérei a fő múvének tartott) - e munkák üzenetét elôször Pataki Ferenctôl hallottuk. Ô maga is látogatta Méreit a laboratóriumi „számúzetés” cseppet sem cellányi világában, ahol a lelkek éppoly nyitottá váltak, mint a függöny nélküli ablakok és a nevezetes piros bársonyhuzatú fotel, ezek a Tanár úr meghittséget teremtô légkörének szimbólumává is váltak.

Hogyan is alakultunk meg pszichodráma múhelycsoportként?

Egyrészt azokból a tanítványokból lettünk, akik a Tanár Úrhoz csoportba jártak. Így pl. az elsô - életre szóló, máig múködô, nevezetes „A” csoport tagjai közül Kapusi Gyula és Pajor András „áthûtlenkedtek” az M. Cs.-nek (a múhelycsoport rövidítése) nevezett csapatba, ók a „kettôs párttagkönyvúek”. Másrészt a csoport többségét a lipóti tanítványok alkották: Ajkay Klára, Bagdy Emóke, Dobos Emôke, Pál Mária, Láng Iringó, Erdélyi Ildikó (aki szociálpszichológus és „frankofón” volt, irodalompszichológiában, de pszichodrámában is jeles tanítvány) azután Falus Ferenc - a tüdógyógyász pszichoterapeuta, Forgács Péter - a mi „filmesünk”, Kapusi és Pajor, a „duplázók” - mi váltunk az alapcsapattá. Hogyan is?

1974-ben Magyarországon Hidas György és az akkori Pszichoterápiás Módszertani Központ (mi Szinetáriumnak neveztük) munkatársai (Buda Béla, Szônyi Gábor, Harmatta János, Lust Iván) elindították a - ma már történelmi jelentôségú - „Pszichoterápiás Hétvége” mozgalmat. Tíz év alatt húsz magyar városban húsz rendezvényre került sor - ez a hazai pszichoterápiás nyitány -, erre szocializálta a 
hazai szakmai világot a „módszerdemonstrációs” vállalkozás. A Mérei-kör is kezdettôl bekapcsolódott, mindannyian - maga a Tanár úr is - aktívan és teljes létszámban csoportoztunk ezeken az alkalmakon. Mivel a pszichodráma módszere volt az egyik alapeljárásunk, ezzel képviseltük a „Mérei-múhelyt”, alaposan felkészültünk a pszichodrámázásból. Hihetetlen aprólékossággal készített fel bennünket a Tanár úr. A szokásos avantgarde módon - magunk alkotva drámacsoportot - váltott vezetéssel gyakoroltuk a „csoportdinamika-központú” pszichodrámázást. Akkoriban ez volt az egyetlen pszichodramatikus módszer a magyar ég alatt, amely tíz éven át a vezetô irányzatot képviselte.

Ma már történelmi mementó, ami - talán ebben a kötetben helyt kaphat - az akkori múhelycsoport valóságát mutatja be. Ilyenek voltunk, így éltünk és tanultunk együtt ott és akkor. 1981-tôl indult hazánkban a német, késôbb svéd (de magyar származású) dramatisták által közvetített, „protagonista-centrikus” „morenói” pszichodráma. Tíz év alatt el is érte a csoportcentrikus Mérei-módszer háttérbe szorítását. Ma kizárólagosan a Mérei-féle drámamódszerrel már csak a mi csoportunk és Szakács Ferenc dolgozik - a húséges Mérei-tanítvány, aki egyedül volt és maradt a Tanár úr „fia”, primus inter pares - az egyenlôk közt is elsô. Ez évben vette át a Magyar Pszichológiai Társaság életmúdíját (Szakács, 2019).

Az MCS, azaz a Múhelycsoport együtt maradt mindmáig - akárcsak az „elsôszülött”, az „A” csoport, amely a nagy testvér és örök rivális. Tanultunk, továbbképződtünk, igazi mély testvéri-baráti szövetségben élünk ma is - noha közülünk már ketten elindultak Mérei után: Pál Mária és Láng Iringó.

Milyen formában és milyen elvek szerint múködött a múhelycsoportunk?

Miben tért el a morénói pszichodráma elméletétôl és gyakorlatától? Hogyan jelentek meg benne a sajátos, „méreis” elemek, a csoportdinamika, az együttes élmény, az utalás?

Képzeljük csak el, miképp maradhatna fenn egy szoros csoportélet és -kultúra, erre indító imprintingek nélkül? Megalakulásunk a hetvenes évek elejére esik. Abban a pszeudodemokratikus világban, amelyben a hallgatás/elhallgatás izolatív hatása nyomasztotta a lelkünket és az elfojtás oly tökéletes volt, hogy nem is eszméltünk, nincs társas közbeszéd, csak szónoklatok, hallgatások és elhallgatások - a manipulációval behálózni próbálkozó, jólétiséggel beetetô „szocializmusban”, melyet a legvidámabb barakknak tituláltunk, a Mérei-csoport lét számunkra a szabadság volt maga.

A módszer csoportdinamika központú, azaz a frissiben keletkezô, közös érdeklődéssel továbbszôtt téma alkotja a játék lelkét. A játékba emelést Mérei „buggyantás”-nak nevezte. A megelevenítésben a spontaneitás szabadsága érvényesülhetett, a módszertani elemek (kettôzés, belsố hang, kisegítô én stb.) improvizatív módon kerülhettek be a játékba, amelynek kimenetelét a csoport minden tagja befolyásolhatta. Nagy kohezív erejú, összetartozó csoportok szervezôdtek az együttes élményeknek köszönhetốen, sokat tanultunk a rejtett dinamika felismeréséból, megértéséból.

Ôszinte, szabad, spontán emberi lét, örömben és alkotó fáradozásban - ez olyan mély bevésôdéssé vált, hogy immár halálunkig elkísér. Nagy életajándék ez mindannyi- 
unknak, Mérei-örökség, amelyet egyikünk - Bagdy Emôke - a Károli Gáspár Református Egyetemen Erdélyi Ildikóval együttesen - buzgón továbbörökített. Aki a Károlin Erdélyitôl, Bagdytól tanult, képződött pszichológusokkal beszél, az rögvest felismeri ezt a másságot. Az önismereti tudatosság elfogadása és a csoportlét kultusza ez.

\section{Hogyan mutatkozott meg a Tanár úr „életszemlélete” a munka során?}

Munkájában és társas kapcsolataiban ugyanaz a „bandázs nélküli”, szabad, a kreativitást és teljesítményt, spontaneitást és játékot tisztelő-múvelő originális jelenség volt. Nem a fizikuma keltett feltünést, ha valahol megjelent, hiszen kistermetú volt, az öltözködésére sem adott, egyszerú nejlonszatyrokkal járt - stílustalanul, lezser nemtörôdömséggel. A lényéból áradó jelenlét, odafigyelés, involváltság tette jelentôssé. A binswangeri prezencia ez, annak éreztetése, hogy itt és most csak a te számodra vagyok jelen, nem létezik más fontosság. Nem tudjuk, hogyan csinálta, ez az elleshetetlen, ez a tehetség. Szerette az életet. Tanítványainak (ezek mi voltunk, a Múhelycsoport) interjút adva 1985-ben ezt így fogalmazta meg: „A szabadság elsô pontja: szeretni az életet.” Itt - most - ma, mert „nem várom az életet, hanem élem” - mondta (Bagdy, 1985). Súlya lett a szavainak köztünk, mert hiteles volt. Azt kívánta, hogy teljesítsünk. Sorra doktoráltunk a Lipóton, szinte könyörtelen volt a követelésben - féltünk is az ítéletétôl. A kisebb tévedést is szigorúan ítélte el. Ha mulasztottunk, késtünk, a Farkasrétet javasolta, ahol lazsálhatunk, a temetôben nincs feladat. Ugyanakkor ó is úgy élt, ahogy tôlünk kívánta. Fáradhatatlan volt, túltett mindenkin, az erejét meghaladóan tudott erôfeszíteni. Egy kisebb agyérkrízise után a lipóti szobája pamlagán fekve azt kérte, számoltassuk, beszéltessük, kérdezzük, gondolkodtassuk, hogy ellenôrizze a sérültsége mértékét. Szellemi feladatokat kért, és megterhelésnek vetette alá magát. Más vajon mit tenne ilyenkor? Szerintünk ó volt a helytállás, kitartás és túlélés bajnoka. Munkaszolgálatosként 120 kg-os ládákat rakodott, de rogyadozva is kitartott. A sajnálkozó tisztnek azt mondta a társa: „Hagyd el, neki a legkönnyebb, lélekból csinálja!” A történetrôl az elaboráció kapcsán maga a Tanár úr számolt be, „félelem helyett elaboráció” - ezt tanította, és azt javasolta, hogy még a konfliktusainkat is szeressük, bánjunk velük jól, ne ellenük dolgozzunk, hanem velük.

Amikor dolgozott, körülötte spontán formálódott alkotómúhely. Bevonó, elsodró hatású volt, tekintélyszemélyiség, aki egyszersmind szeretettel, de legalábbis elfogadással fordult felénk. Nem a szemlélete mutatkozott meg a munkájában, hanem ó maga volt a minta, miközben - Csíkszentmihályi fogalmazásával szólva „autotelikus élményben”, önátadó azonosulásban vált eggyé a tárgyával. Konceptualizálni, megragadni a jelenséget, szinte jelenésképpen felmutatni, tisztán gondolkodni, tisztelni a tényeket, szeretni az igazságot és precíznek lenni, szépen írni és szólni, magas hôfokon átélni az élménybe bevetettség állapotait, de nyitott szemmel, „bandázs nélküli bajvívásban” és tudatosító önismerettel feldolgozni az átélteket - ez volt ô, ezt lestük el tôle. Átvettük a csoportlét kultúráját is, mert jól éreztük magunkat a csoportjaiban. Jó volt dramatizáló játékban megélni és azután feldolgozva megérteni magunkat, egymást és a világ dolgait - múltat - jelent, sốt megidézni a jövôt. „Szépnek az éhét. Igaznak a szomját” tanította azzal, ahogyan élt és dolgoztatott bennünket. 
Valójában a megragadhatatlant kísérletezgetjük élményközelbe hozni, amikor arra emlékezünk, hogyan dolgozott. Minden személyi kultusz nélkül állíthatjuk: nyomokat hagyó, befolyásoló, bevonó módon, varázslatosan élt, dolgozott, alkotott, tanított, mi pedig tanultuk ôt és tanultunk tôle: ez többünk számára mindmáig a szakma-családi szocializáció érvényes modellje. Egyik csoporttársunk a szakmai-szellemi apjának tekintette.

„Egyik agóniámban szép és okos lányokat és fiúkat képzeltem magam köré, s a velük való kapcsolat folyamatossága teszi lehetôvé, hogy sok évig túléljem saját életemet” - írta nekünk Lélektani napló IX. címú (eddig kiadatlan) kötetében. Futurológiai víziója valóssággá vált, noha tudjuk, hogy velünk - az ôt ismerố tanítványokkal - együtt egyszer majd a rá való emlékezés lélekmécsesei is kihunynak. De addig... addig égnek a lángok, és mi továbbadjuk a tanításokat és az életmintát.

\section{Melyek a legfontosabb pontok, amelyekben a Tanár úr hatással volt gondolkodásunkra és munkánkra?}

Mérei Tanár úr hatása nem köthetô pontokhoz, területekhez. Létezéstudományt és életmúvészetet tanultunk tôle, noha az eredményességen van elmélkednivalónk. Vannak, akik a világban való részvételnek, vannak, akik a világ magyarázatának a zsenijei. A kettô együtt volt Méreiben, mint jin és jang, sötétség és fény. Az ellentétek feszültsége és harmóniája együtt volt jelen személyisége ellentmondásos teljességében. Egyikünk pl. tôle kapta pályája legfontosabb üzenetét. Diploma bankettjük éjszakáján távirat érkezett, benne az üzenet: „Erôt, derüt és több bátorságot kíván a pályájához M. F.” Ahogyan emlékezik, éppen erre a biztatásra volt szüksége. Legfóképpen az életbátorság üzenetét érezte akkor aktuálisnak, néha még ma is. Paul Tillich - a teológus-filozófus - is a „Courage to be”-t tekinti a legfőbb jónak. Igaza van. Életigenlés, a helyzetekben való jelenlét fontossága, az uralom helyett bizalom és bizakodás, a gondok fölé kapaszkodó lélekerô, az elaboráció képessége és a magas hôfokon élés, mindez az ó életmintájára erôsödött meg bennünk.

A pedagógiai éroszban is követjük ôt. Továbbvisszük a „múhelységet”, a csoportkultúrát, a rorschachozás sajátos magyar irányzatát, az együttes élményt pedig a pályaszocializációban, de még a szupervizió szakágának képviseletében is folytonosan gondozzuk. A szakmai személyiség csiszolgató tökéletesitését fölöttébb fontos ügynek, sốt missziónak tekintjük. Ebben is sokat merítettünk az ô forrásából.

\section{Tartjuk-e a kapcsolatot más Mérei-tanítványokkal?}

Igen. Mi „több fészekalja gyermek”, de egy család vagyunk. Úgy véljük, hogy a Tanár úr a három apától több testvér saját származási családi helyzetet, annak minden egykori feszültségét a mi csoportjaink létrehozásával, az „A”, MCS és single gyermekek életépítményében oldotta meg és dolgozta fel igazán. Bebizonyította, hogy a sok rivális és a „kié az apa” privilégiumáért vetélkedó testvérek között is lehet életre szóló szeretetkötelék. Átjárunk „privatizálni” egymáshoz, de nem elegyülünk. Szinkretikus 
csoportkísérletünkkel hamar felhagytunk, de a kötelék olyan erôs, hogy még az egykori Mérei-laborban gyakorlatot töltött vagy ott tanult pszichológusok is „Méreihez tartozónak” vallják magukat. A múhelycsoport, azaz „MCS” ma is havonta egyszer egy hosszú estét tölt együtt. A szakmai örökség áldásával a fejünkön és szívünkben - húséges tanítványok maradunk - csoport- (múhely)tagként is örökös és végleges.

\section{Milyen Mérei körüli konfliktusokra emlékezünk?}

Sokfélére, de ezek nem is politikai jellegúek voltak, még csak nem is kortárs pszichológusokkal, fôleg nem férfiakkal kapcsolatosak. Elsôsorban abból eredtek, hogy erôs kötôdéseket tudott kialakítani, és mind a tanítványi rivalizációban, mind a nôi vonzalmak hálójában nagy szcénák tudtak körülötte és vele történni. Hankiss Ágnes (1989) idézte utalásképpen - a Tanár Úrra emlékezvén az emlékülésen - rabbi Elijahut, a szigorú erkölcsû́ rabbit, aki egy meditatív órájában fúszálat rágcsálva és az ujjain legördülő esốcseppeken elmerengve egyszerre csak azt találta mondani: aki még nem szeretett asszonyt szenvedélyes szerelemmel, az nem tudhatja azt sem, mi az Isten-szeretet. Minderrôl nekünk sincs több mondanivalónk.

\section{IRODALOM}

Bagdy E. (1985). „A szabadság elsố pontja: szeretni az életet” - Beszélgetés a 75 éves Mérei Ferenccel. Magyar Pszichológiai Szemle, 42(1), 241-253.

Hankiss Á. (1989). Filozófus és Kalandkeresô - Mérei Ferenc 80. születésnapjára. In Forgács P., Pál M. \& Bagdy E. (szerk.), Mérei Ferenc Emlékkönyv (pp. 98-101.). Budapest: MPT Animula Egyesület.

Szakács F. (2010). November 100. (Szubjektív emlékezés Mérei Ferencre). Magyar Pszichológiai Szemle, 65(2), 343-350.

Szakács F. (2019). Mérei Ferenc és a hazai klinikai pszichológia sztenderdjei. In Pléh Cs., Mészáros J., Csépe V. (szerk.), A pszichológiatörténet-írás módszerei és a magyar pszichológiatörténet (pp. 395-340.). Budapest: Gondolat Kiadó. 


\title{
ON THE OCCASION OF THE $110^{\text {th }}$ ANNIVERSARY OF THE BIRTH OF FERENC MÉREI, FOUNDER OF THE CLINICAL PSYCHOLOGY PROFESSION IN HUNGARY
}

\author{
AJKAY, KLÁRA - BAGDY, EMŐKE - DOBOS, EMŐKE - ERDÉLYI, ILDIKÓ - \\ FALUS, FERENC - KAPUSI, GYULA - PAJOR, ANDRÁS
}

\begin{abstract}
This paper is the result of the collaborative and commemorative work of the "Psychodrama Workshop Group" (hereafter WG). Our aim was to embed the origins of our group, which is still active today, in historical processes such as the "conquest" of clinical psychology that occurred in the "Lipótmezö".

Ferenc Mérei, widely known as "the teacher", was the creator and founder of the Hungarian clinical psychology practice. With this commemorative project, we aim to present Mérei's personality, his teaching philosophy and his work in framing the psychological profile of the profession.

His teaching of "Rorschaching" was an integral part of his professional educational work, which combined the necessity of theoretical knowledge with psychology practice ("doing", as he called it) and the development of psychologists' professional habitus. This paper thus expresses our respect for Mérei's creative talent and serves as a memento to his activities in shaping the profession. To this end, we pursue eight specific questions that are informed by our commemorative approach.
\end{abstract}

Keywords: Mérei, psychodrama, Rorschach

A cikk a Creative Commons Attribution 4.0 International License (https://creativecommons. org/licenses/by/4.0) feltételei szerint publikált Open Access közlemény, melynek szellemében a cikk bármilyen médiumban szabadon felhasználható, megosztható és újraközölhetô, feltéve, hogy az eredeti szerzố és a közlés helye, illetve a CC License linkje és az esetlegesen végrehajtott módosítások feltüntetésre kerülnek. (SID_1) 